\title{
Screen Personal Tool to Improve Students Understanding of The Concept Of Summing Round Numbers in SDN 1 Linggasari
}

\author{
Hendi Novianto
}

SDN 1 Linggasari

hendinovianto@gmail.com

\section{Article History}

accepted 14/11/2020

approved $21 / 11 / 2020$

published 26/11/2020

\begin{abstract}
The background of the writer is the students' lack of understanding of the concept of adding make numbers. While the purpose of this study is to determine how much influence the use of number line props on student motivation. And to find out how much influence the number line props have on understanding of the teaching material. The method that I use is to use number line props on the concept of adding whole numbers. This research was conducted through a cycle assessment process consisting of four stages (planning, implementing, observing, and reflecting) in three cycles of learning improvement. From the results of the analysis, the conclusions obtained from this study are: 1) The use of number line props in the material of adding whole numbers can increase students' understanding by $71.79 \%$, namely from the initial condition $28.21 \%$ to $100 \%$ in the third cycle. 2) The use of number line props on the sum of integers material can increase the seriousness of students by $74.36 \%$, namely from the initial condition $25.64 \%$ to $100 \%$ in the third cycle. Conclusions from this study Is an effective use of number line props to improve understanding of integers.
\end{abstract}

Keywords: Student understanding, number line divider, addition of integers

\begin{abstract}
Abstrak
Latar belakang penulis adalah kurangnya pemahaman siswa tentang konsep penjumlahan bilangan bulat. Sedangkan tujuan penelitian ini adalah untuk mengetahui seberapa besar pengaruh penggunaan alat peraga garis bilangan terhadap motivasi belajar siswa. Dan untuk mengetahui seberapa besar pengaruh alat peraga garis bilangan terhadap pemahaman materi ajar. Metode yang saya gunakan adalah dengan menggunakan alat peraga garis bilangan pada konsep penjumlahan bilangan bulat. Penelitian ini dilaksanakan melalui proses penilaian siklus yang terdiri dari empat tahap (perencanaan, pelaksanaan, observasi, dan refleksi) dalam tiga siklus peningkatan pembelajaran. Dari hasil analisis diperoleh kesimpulan dari penelitian ini adalah: 1) Penggunaan alat peraga garis bilangan pada materi penjumlahan bilangan bulat dapat meningkatkan pemahaman siswa sebesar $71,79 \%$ yaitu dari kondisi awal $28,21 \%$ menjadi $100 \%$ pada siklus III. 2) Penggunaan alat peraga garis bilangan pada materi penjumlahan bilangan bulat dapat meningkatkan keseriusan siswa sebesar $74,36 \%$ yaitu dari kondisi awal $25,64 \%$ menjadi $100 \%$ pada siklus III. Kesimpulan dari penelitian ini Apakah penggunaan alat peraga garis bilangan efektif untuk meningkatkan pemahaman tentang bilangan bulat.
\end{abstract}

Kata kunci: pemahaman siswa, pembatas garis bilangan, penjumlahan bilangan bulat

Social, Humanities, and Education Studies (SHEs): Conference Series https://jurnal.uns.ac.id/shes

p-ISSN 2620-9284

e-ISSN 2620-9292 


\section{PENDAHULUAN}

Terkait dalam hal matematika, proses pembelajaran matematika akan berhasil atau tidaknya juga tergantung dari profesionalisme guru itu sendiri, sebagai salah satu komponen penting penentu keberhasilan pembelajaran. Guru memang dituntut untuk mampu melaksanakan tugasnya dengan baik. Untuk itu guru harus menguasai berbagai kompetensi demi keberhasilan pendidikan itu sendiri. Ini berarti guru tidak hanya dituntut menguasai materi pelajaran atau mampu menyajikan secara tepat, tetapi juga mampu menilai kinerja sendiri. Untuk yang paling tahu tentang segala sesuatu yang terjadi di kelasnya adalah guru.

Berkenaan dengan hal itu penyusun menyadari sepenuhnya masalah-masalah yang selalu muncul dalam kegiatan pembelajaran. Seringkali penyusun merasa bingung menentukan model pembelajaran atau metode mengajar apa yang akan digunakan dalam proses pembelajaran. Seperti dalam proses pembelajaran sebelum mengubah media pembelajaran, siswa kurang bersungguh - sungguh dalam kegiatan, diberi tugas main sendiri, tidak berani bertanya, kurang percaya diri dalam menjawab pertanyaan guru, kurang bersemangat dalam mempelajari materi pembelajaran serta hasil tes yang dicapai rendah. Dari 39 siswa hanya 11 siswa yang mendapat nilai di atas 60 (kriteria ketuntasan minimal ). Ini berarti yang mencapai ketuntasan belajar hanya $28,21 \%$.

Menyadari keadaan tersebut, penyusun melakukan diagnosa terhadap pembelajaran yang telah dilakukan kemudian mencoba untuk melakukan perbaikan melalui Penelitian Tindakan Kelas ( PTK ) di tempat penyusun bertugas. Untuk melakukan perbaikan pembelajaran sebelumnya dilakukan identifikasi masalah. Berdasarkan fakta di atas penyusun meminta bantuan teman sejawat untuk membantu mengidentifikasi kekurangan dan pembelajaran yang telah dilakukan. Dari hasil diskusi terungkap beberapa masalah yang terjadi dalam pembelajaran, yaitu :

a. Pemahaman siswa terhadap materi yang diajarkan rendah.

b. Siswa kurang bersungguh - sungguh dalam belajar.

Untuk mengetahui penyebab timbulnya masalah perlu dilakukan analisis. Berdasarkan hasil refleksi diri, kajian berbagai dokumen dan diskusi dengan teman sejawat diprediksikan faktor penyebab rendahnya tingkat pemahaman/kemampuan dan rendahnya minat belajar siswa terhadap materi yang diajarkan adalah :

a. Alat peraga yang digunakan guru kurang menarik.

b. Penyusun kurang mampu menciptakan kondisi pembelajaran yang membangkitkan motivasi belajar siswa.

Berdasarkan kedua faktor penyebab di atas maka alternatif pemecahan masalah yang akan ditempuh diorientasikan pada penggunaan media pembelajaran yang sesuai dengan perkembangan kognitif siswa. Dalam hal ini penyusun memilih penggunaan alat peraga garis bilangan yang dapat meningkatkan pemahaman belajar siswa. Tujuan penelitian ini adalah untuk mengetahui seberapa besar pengaruh penggunaan alat peraga garis bilangan terhadap motivasi belajar siswa dan untuk mengetahui seberapa besar pengaruh alat peraga garis bilangan terhadap pemahaman terhadap materi ajar.

\section{METODE}

Data yang dikumpulkan meliputi data kualitatif dan data kuantitatif. Data kuantitatif berkaitan dengan proses pembelajaran, sementara data kuantitatif berkaitan dengan hasil belajar siswa. Instrumen yang digunakan untuk mengumpulkan data berupa lembar penilaian formatif, kerja kelompok, dan lembar observasi. Data kuantitatif akan diolah melalui analisis deskriptif, sedangkan data kualitatif akan diolah dalam bentuk paparan narasi yang menggambarkan kualitas pembelajaran. 
1. Hasil Pengolahan Data

HASIL DAN PEMBAHASAN

Berdasarkan tes dan observasi diketahui hasil perbaikan pembelajaran baik pemahaman dan kesungguhan siswa dalam belajar. Untuk lebih jelasnya perhatikan data di bawah ini :

a. Pemahaman Siswa Terhadap Materi Penjumlahan Bilangan Bulat

Tabel 1. Rekapiyulasi Nilai Formatif Pembelajaran Matematika Terhadap Materi Penjumlahan Bilangan Bulat pada Studi Awal, Siklus I, Siklus II, dan Siklus III

\begin{tabular}{llccccc}
\hline No & Nama Siswa & Studi & & Siklus & & Ket. \\
& & Awal & I & II & III & \\
\hline 1 & Angga Apriansah & 40 & 40 & 60 & 70 & Tuntas \\
2 & Dwi Setianingsih & 40 & 40 & 60 & 70 & Tuntas \\
3 & Ruli Fatonah & 40 & 40 & 60 & 70 & Tuntas \\
4 & Rizki Andika & 40 & 40 & 60 & 80 & Tuntas \\
5 & Wawan Apriyanto & 80 & 80 & 80 & 100 & Tuntas \\
6 & Ade Setiawan & 40 & 40 & 60 & 70 & Tuntas \\
7 & Amelia Wahyu Utami & 40 & 60 & 80 & 80 & Tuntas \\
8 & Agis Saputra & 40 & 40 & 40 & 70 & Tuntas \\
9 & Anggita Permata. C & 80 & 100 & 100 & 100 & Tuntas \\
10 & Dwi Setiya Wibowo & 40 & 40 & 60 & 70 & Tuntas \\
11 & Dwi Azis & 40 & 40 & 60 & 70 & Tuntas \\
12 & Fikri Mahalani & 40 & 40 & 40 & 70 & Tuntas \\
13 & Fredi Irawan & 40 & 60 & 60 & 80 & Tuntas \\
14 & Feri Gustiana & 40 & 60 & 40 & 70 & Tuntas \\
15 & Galih Okta & 40 & 40 & 40 & 70 & Tuntas \\
16 & Indri Cahyani & 80 & 80 & 80 & 100 & Tuntas \\
17 & Indra Cahyono & 40 & 40 & 40 & 70 & Tuntas \\
18 & Ifah Umiati & 40 & 40 & 60 & 70 & Tuntas \\
19 & Jamaludin Hidayah & 40 & 40 & 40 & 70 & Tuntas \\
20 & Kurniawati, N.P.A & 40 & 80 & 100 & 100 & Tuntas \\
21 & Lita Riana & 60 & 80 & 80 & 80 & Tuntas \\
22 & Lili Indrayani & 40 & 40 & 40 & 70 & Tuntas \\
23 & Nur Khofaiq & 40 & 60 & 80 & 80 & Tuntas \\
24 & Pujianto & 40 & 60 & 60 & 70 & Tuntas \\
25 & Rizki Nurokhman & 40 & 60 & 80 & 80 & Tuntas \\
26 & Rizki Kurniawan & 40 & 40 & 40 & 70 & Tuntas \\
27 & Ragil Suseno & 40 & 40 & 40 & 70 & Tuntas \\
28 & Sri Wahyuni & 40 & 60 & 80 & 80 & Tuntas \\
29 & Sarah Nurfiah & 80 & 80 & 80 & 80 & Tuntas \\
30 & Sutoro & 40 & 40 & 40 & 70 & Tuntas \\
31 & Titin Mujayanah & 40 & 60 & 80 & 80 & Tuntas \\
32 & Umi Syarifah & 80 & 80 & 80 & 100 & Tuntas \\
33 & Velda Mega Utami & 40 & 40 & 40 & 70 & Tuntas \\
34 & Wahyu Puspita & 80 & 80 & 80 & 100 & Tuntas \\
35 & Wahyu Aditya. A & 60 & 60 & 80 & 80 & Tuntas \\
36 & Oke Ragil Pamungkas & 40 & 40 & 60 & 70 & Tuntas \\
37 & Astrika Febianti & 80 & 80 & 80 & 100 & Tuntas \\
\hline & & & & & & \\
\hline
\end{tabular}




\begin{tabular}{llccccl}
\hline 38 & Dio Imaduddin & 80 & 80 & 80 & 100 & Tuntas \\
39 & Tri Putra Mahardika & 40 & 60 & 80 & 80 & Tuntas \\
& JUMLAH & 1960 & 2160 & 2500 & 3080 & \\
& RATA - RATA & 50,26 & 55,38 & 64,10 & 78,97 & \\
\hline
\end{tabular}

Dari Tabel 1 diperoleh keterangan sebagai berikut :

1. Pada studi awal, siswa yang tuntas belajar sebanyak 11 siswa dari 39 siswa ( $28,21 \%$ ) dengan nilai rata - rata 50,26 .

1. Pada siklus I, siswa yang tuntas belajar sebanyak 19 siswa dari 39 siswa ( 48,72\%) dengan nilai rata - rata 55,38.

2. Pada siklus II, siswa yang tuntas belajar sebanyak 28 siswa dari 39 siswa ( $71,79 \%$ ) dengan nilai rata - rata 64,10 .

3. Pada siklus III, siswa yang tuntas belajar sebanyak 39 siswa dari 39 siswa ( $100 \%$ ) dengan nilai rata - rata 78,97.

Sedangkan siswa yang belum tuntas dalam belajar adalah sebagai berikut :

1. Pada studi awal, siswa yang belum tuntas sebanyak 28 siswa dari 39 siswa $(71,79 \%)$.

2. Pada siklus $I$, siswa yang belum tuntas sebanyak 20 siswa dari 39 siswa ( $51,28 \%$ ).

3. Pada siklus II, siswa yang belum tuntas sebanyak 11 siswa dari 39 siswa ( $28,21 \%)$.

4. Pada siklus III, siswa yang belum tuntas sebanyak 0 siswa.

Setelah dilakukan analisis terhadap data pada tabel $1.1 \mathrm{di}$ atas bahwa tingkat pemahaman siswa setelah penggunaan alat peraga garis bilangan menunjukkan kenaikan angka ketuntasan yang sangat signifikan.

Tabel 2 Rekapitulasi Ketuntasan Belajar Siswa pada Setiap Siklus Kegiatan Perbaikan Pembelajaran.

\begin{tabular}{llcccc}
\hline \multirow{2}{*}{ No } & \multirow{2}{*}{ Pembelajaran } & \multicolumn{4}{c}{ Hasil Belajar Siswa } \\
\cline { 3 - 6 } & & Tuntas & Persentase & Belum & Persentase \\
\hline 1 & Studi Awal & 11 & 28,21 & 28 & 71,79 \\
\hline 2 & Siklus I & 19 & 48,72 & 20 & 51,28 \\
\hline 3 & Siklus II & 28 & 71,79 & 11 & 28,21 \\
\hline 4 & Siklus III & 39 & 100 & 0 & 0 \\
\hline
\end{tabular}

Dari tabel 2. tersebut diperoleh keterangan sebagai berikut :

1. Pada siklus I, angka ketuntasan siswa naik $20,51 \%$ ( bertambah 8 siswa dari studi awal ).

2. Pada siklus II, angka ketuntasan siswa naik $23,08 \%$ ( bertambah 9 siswa dari siklus I ).

3. Pada siklus III, angka ketuntasan siswa naik 28,21\% ( bertambah 11 siswa dari siklus II ).

Untuk lebih jelasnya peningkatan ketuntasan belajar siswa dan rerata dapat dilihat pada gambar diagram batang berikut ini : 


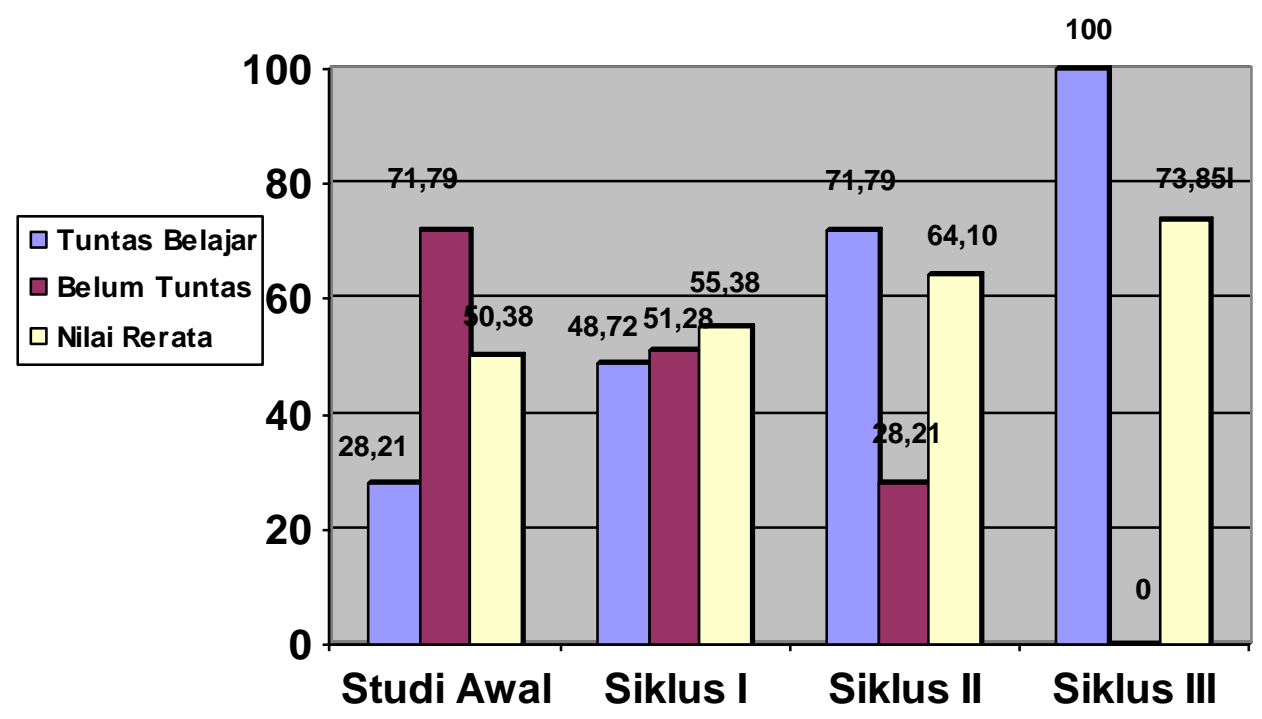

\section{Gambar 1. Diagram Batang Angka Ketuntasan, Ketidaktuntasan dan Nilai Rerata pada Setiap Siklus Kegiatan Perbaikan Pembelajaran}

b. Kesungguhan Siswa dalam Belajar

Dari hasil analisis, peningkatan kesungguhan belajar siswa pada setiap siklus kegiatan pembelajaran dapat dilihat pada tabel berikut ini:

Tabel 3. Rekapitulasi Peningkatan Kesungguhan Belajar Siswa untuk Setiap Siklus Kegiatan Perbaikan Pembelajaran

\begin{tabular}{llcl}
\hline No & $\begin{array}{c}\text { Kegiatan } \\
\text { Pembelajaran }\end{array}$ & $\begin{array}{c}\text { Siswa Menunjukkan } \\
\text { Kesungguhan }\end{array}$ & Presentase \\
\hline 1 & Studi Awal & 10 & 25,64 \\
\hline 2 & Siklus I & 13 & 33,33 \\
\hline 3 & Siklus II & 30 & 76,92 \\
\hline 4 & Siklus III & 39 & 100 \\
\hline
\end{tabular}

Dari tabel 2.3 di atas dapat diperoleh keterangan sebagai berikut :

1. Pada studi awal, siswa yang menunjukkan kesungguhan belajar 10 siswa atau $25,64 \%$.

2. Pada siklus I, siswa yang menunjukkan kesungguhan belajar 13 siswa atau $33,33 \%$.

3. Pada siklus II, siswa yang menunjukkan kesungguhan belajar 30 siswa atau $76,92 \%$.

4. Pada siklus III, siswa yang menunjukkan kesungguhan belajar 39 siswa atau $100 \%$.

5. Pada studi awal ke siklus I, kesungguhan belajar siswa naik $7,69 \%$.

6. Pada siklus I ke siklus II, kesungguhan belajar siswa naik $41,03 \%$.

7. Pada siklus II ke siklus III,kesungguhan belajar siswa naik $23,08 \%$

Untuk lebih jelasnya peningkatan kesungguhan belajar siswa dapat dilihat pada gambar diagram batang berikut ini : 
SHEs: Conference Series 3 (3) (2020) 1292- 1300

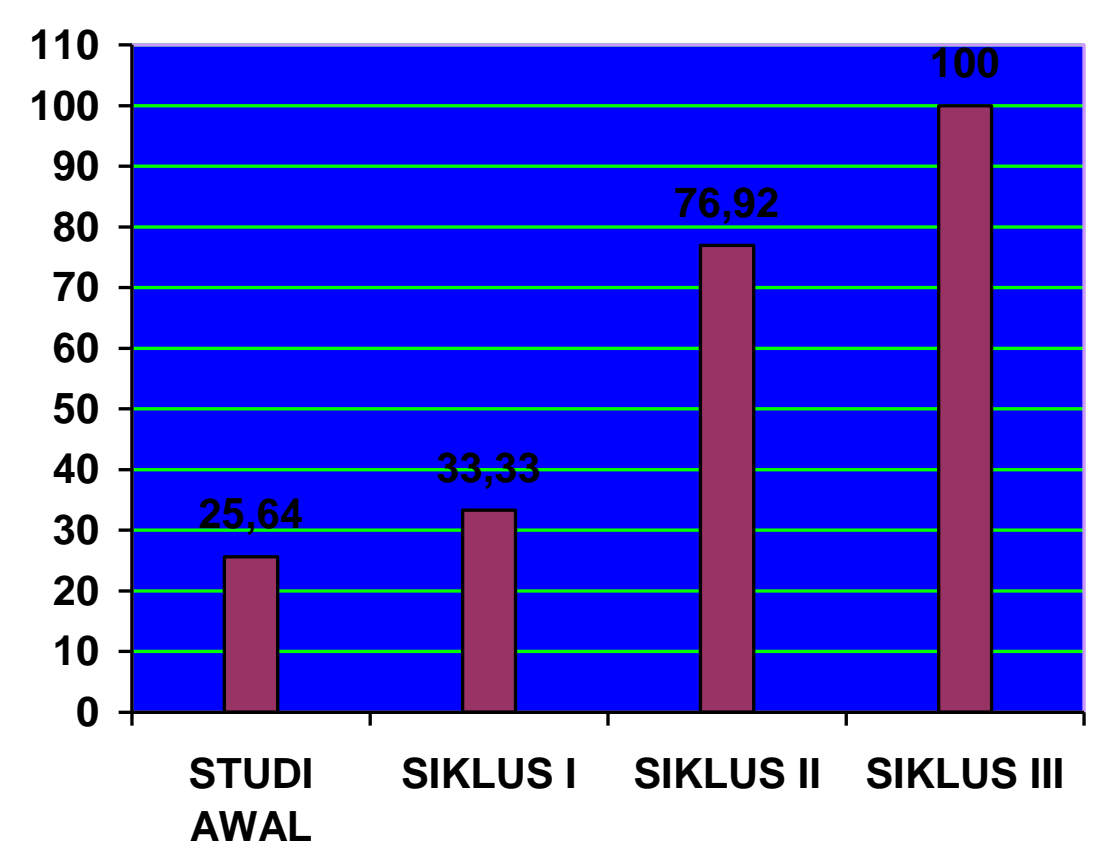

\section{Gambar 2 Diagram Batang Peningkatan Kesungguhan Belajar Siswa pada Setiap Siklus Kegiatan Perbaikan Pembelajaran}

2. Deskripsi Hasil dan Refleksi

\section{a. Siklus I}

Pada studi awal, siswa yang tuntas belajar sebanyak 11 siswa dari 39 siswa ( $28,21 \%$ ) dengan rerata 50,26 sedangkan siswa yang sunguhsungguh dalam belajar 10 siswa dari 39 siswa ( $25,64 \%$ ). Setelah dilaksanakan perbaikan pembelajaran pada siklus pertama, jumlah siswa yang tuntas belajar menjadi 19 siswa dari 39 siswa (48,72\%) dengan nilai rerata 55,26 , sedangkan siswa yang menunjukkan kesungguhan dalam belajar menjadi menjadi 13 siswa dari 39 siswa ( 33,33 $\%$ ). Ini berarti ada kenaikan ketuntasan belajar sebesar 20,51\%, kenaikan kesungguhan belajar sebesar $7,69 \%$, dan kenaikan nilai rerata sebesar 5,12 . Perubahan penggunaan alat peraga garis bilangan mampu meningkatkan pemahaman siswa dalam belajar.

Dari hasil analisis dan refleksi pada siklus pertama ternyata tingkat ketuntasan belum sampai pada batas kriteria yang ditetapkan. Hanya 11 siswa dari 39 siswa yang mencapai tingkat ketuntasan dan hanya 10 siswa dari 39 siswa yang menunjukkan kesungguhan dalam belajar.

Dari hasil diskusi dengan teman sejawat, gejala umum yang terjadi pada siswa yang belum memahami konsep penjumlahan bilangan bulat dan ini disebabkan pada kelompok yang paling belakang kurang jelas. Akhirnya mereka melakukan aktivitas sendiri. Dari kelompok ini pula yang terindentifikasi termasuk kelompok yang tidak bersungguh - sungguh dalam belajar.

Untuk mengatasi keadaan ini upaya yang dilakukan pada siklus kedua dengan melakukan perubahan alat peraga yaitu dengan diberi warna pada arah panah yang menunjukkan bilangan positif dan arah panah yang menunjukkan bilangan negatif. 
b. Siklus II

Setelah dilaksanakan perbaikan pembelajaran, jumlah siswa yang tuntas belajar mengalami kenaikan menjadi 28 siswa dari 39 siswa $(71,79$ $\%$ ) dengan nilai rerata 64,10 . Sedangkan siswa yang sungguh-sungguh dalam belajar naik menjadi 30 siswa dari 39 siswa (76,92 \% ). Ini berarti ada kenaikan ketuntasan belajar sebesar 23,08 \%, kenaikan kesungguhan belajar siswa sebesar $39,59 \%$ dan kenaikan nilai rerata 8,72 . Perubahan alat peraga garis bilangan dapat meningkatkan pemahaman dan kesungguhan belajar siswa.

Setelah dilakukan perubahan alat peraga terdapat kenaikan di semua aspek. Walaupun ketuntasan belajar masih di bawah kriteria. Jumlah siswa yang tuntas belajar naik menjadi 28 siswa dari 39 siswa dan siswa yang menunjukkan kesungguhan dalam belajar mencapai 30 siswa dari 39 siswa.

Dari hasil diskusi balikan, gejala yang paling umum terjadi pada siswa yang belum tuntas, tidak bersungguh - sungguh dalam mengerjakan tugas dan bercerita sendiri sehingga kurang jelas dalam menerima pelajaran dan juga karena jumlah kelas yang terlalu banyak.

Untuk mengatasi keadaan ini, perbaikan di siklus ketiga dicoba dengan melakukan perubahan alat peraga lagi dengan memberi angka pada arah panah yang menunjukkan bilangan positif dan arah panah yang menunjukkan bilangan negatif. Dan juga dengan melaksanakan diskusi kelompok.

c. Siklus III

Setelah dilaksanakan perbaikan pembelajaran, jumlah siswa yang tuntas belajar menjadi 39 siswa dari 39 siswa ( $100 \%$ ) dengan nilai rerata 73,85. Sedangkan siswa yang menunjukkan kesungguhan dalam belajar naik menjadi 39 siswa dari 39 siswa ( $100 \%$ ). Ini berarti ada kenaikan ketuntasan belajar sebesar 28,21 \%, kenaikan kesungguhan belajar sebesar $25,08 \%$ dan kenaikan nilai rerata sebesar 9,75. Perubahan alat peraga lagi dengan memberi angka pada arah panah yang menunjukkan bilangan positif dan arah panah yang menunjukkan bilangan negatif. Dan juga dengan melaksanakan diskusi kelompok, hasilnya semua siswa tuntas dalam belajar dan jumlah siswa yang menunjukkan kesungguhan dalam belajar sebanyak 39 siswa. Ini berarti perbaikan pembelajaran sudah berhasil jauh melampaui kriteria yang telah ditentukan, maka upaya perbaikan berakhir pada siklus ketiga.

1. Siklus I

Alternatif pemecahan masalah untuk mengatasi rendahnya pemahaman siswa terhadap penjumlahan bilangan bulat dan rendahnya kesungguhan belajar siswa dengan menggunakan alat peraga garis bilangan dalam pembelajaran penjumlahan bilangan bulat di kelas IV SD Negeri 3 Linggasari, ternyata memberikan kenaikan hasil belajar dan kesungguhan belajar yang signifikan dibandingkan dengan studi sebelumnya.

Berkat intervensi ini ada kenaikan ketuntasan belajar siswa sebesar $20,51 \%$, kenaikan rerata 5,12 dan kenaikan kesungguhan belajar siswa 7,69 $\%$. Hal ini seperti yang dikatakn Jerome S. Bruner( dalam Udin S.Winataputra 2007 : 3.15 ) motivasi adalah kondisi khusus yang dapat mempengaruhi individu untuk belajar. Motivasi merupakan variabel penting, khususnya selama proses pembelajaran yang dapat membantu, mendorong kemauan belajar siswa. Karenanya, Bruner percaya bahwa hampir semua anak mempunyai masa - masa pertumbuhan akan " keinginan untuk belajar " Reinforcement dan 
reward dari dalam mungkin penting untuk meningkatkan perbuatan tertentu atau untuk membuat mereka yakin hingga mau mengulangi apa yang sudah dipelajari. Bruner menekankan pentingnya motivasi intrinsik dibandingkan dengan motivasi eksternal. Contoh motivasi intrinsik adalah rasa ingin tahu anak. Bahwa dunia ini akan dapat dikenal dan dikuasai anak dengan menggunakan kesadaran " ingin tahu ". Motivasi lain yang dapat membawa kita pada dunia ini adalah dengan memiliki berbagai kompetensi. Anak - anak menjadi tertarik untuk mempelajari hal - hal yang mereka anggap biasa dan telah dikuasai. Satu hal yang tidak mungkin adalah memotivasi anak agar menguasai sesuatu yang mereka tidak biasa dan tidak dikuasai.

2. Siklus II

Setelah dilakukan intervensi terhadap kelemahan hasil refleksi pada siklus I, melalui perubahan alat peraga garis bilangan kenaikan ketuntasan belajar siswa semakin terlihat. Kenaikan ketuntasan belajar sebesar 23,08\%. Kenaikan rerata 8,72 \% dan kenaikan kesungguhan belajar 39,59 \%.

Akan tetapi pada siklus II ini walaupun sudah menunjukkan kenaikan yang signifikan, pemahaman siswa belum melampaui batas kriteria yang telah ditetapkan.

3. Siklus III

Berdasarkan hasil refleksi pada siklus II, penyusun melakukan perubahan alat peraga lagi dengan memberi angka pada arah panah yang menunjukkan bilangan positif dan arah panah yang menunjukkan bilangan negatif. Dan juga dengan melaksanakan diskusi , ternyata upaya tersebut dapat memberikan kontribusi yang signifikan.

Peningkatan pemahaman siswa ( ketuntasan belajar siswa ) naik sebesar 28,21 \%, kenaikan kesungguhan belajar sebesar 23,08 \% dan kenaikan rerata $9,75 \%$. siswa bersungguh - sungguh dalam pembelajaran dan semua siswa memperoleh pengalaman nyata dari pembelajarannya. Seperti dikatakan Edgar Dale bahwa pengalaman belajar yang paling tinggi nilainya adalah pengalaman belajar melalui pengalaman langsung dan melakukan sendiri.

\section{SIMPULAN}

Berdasarkan hasil pengamatan dan tindakan perbaikan pembelajaran yang telah dilaksanakan, dapat diambil kesimpulan sebagai berikut :

1. Penggunaan alat peraga garis bilangan pada pembelajaran penjumlahan bilangan bulat mampu meningkatkan kesungguhan siswa dengan tingkat kesungguhan 100 $\%$.

2. Penggunaan alat peraga garis bilangan meningkatkan pemahaman siswa terhadap materi ajar dengan nilai rata - rata 73,85.

3. Proses bimbingan yang intensif oleh guru selama pembelajaran dapat mempertinggi pemahaman siswa terhadap materi

Dalam penelitian ini ada variable extra yang tidak terkontrol yang dapat dipengaruhi dalam validitas hasil, yaitu faktor pengulangan pembelajaran. Dalam penelitian lebih lanjut sebaiknya efek variable ini diminimalkan. Media berfungsi sebagai jembatan penghubung antara teori dan praktek, antara pendekatan dan teknik berdasarkan metode yang digunakan, maka dapat disusun rancangan pembelajaran baik dari peneliti , siswa, bahan pembelajaran, tujuan kegiatan pembelajaran dan pengajaran. Media pembelajaran yang dirancang dengan baik dapat merangsang timbulnya proses mental pada diri siswa. Dengan perkataan lain, terjadi komunikasi antara siswa dengan media atau secara tidak langsung tentunya antara siswa dengan penyalur pesan ( guru ), dengan demikian kita dapat mengatakan bahwa proses 
belajar mengajar telah terjadi. Media pembelajaran tersebut berhasil menyalurkan pesan / bahan ajar apabila kemudian terjadi perubahan tingkah laku pada diri si belajar ( siswa ).

\section{DAFTAR PUSTAKA}

Ahmadi, Abu \& Widodo. 1991. Psikologi Belajar. Jakarta: Rineka Cipta.

Anitah, Sri \& Janet. 2007. Strategi Pembelajaran Matematika. Jakarta: Universitas Terbuka.

Hernawan, Asep Herry. 2008. Pengembangan Kurikulum dan Pembelajaran. Jakarta: Universitas Terbuka.

Lestari, Hera \& Agus. 2007. Pendidikan Anak di SD. Jakarta: Universitas Terbuka.

Mulyati, Yeti. 2005. Pendidikan Bahasa dan Sastra Indonesia di Kelas Tinggi. Jakarta: Universitas Terbuka.

Muhsetyo, Gatot. 2007. Pembelajaran Matematika SD. Jakarta: Universitas Terbuka. Sumantri, Mulyani. 2007. Perkembangan Peserta Didik. Jakarta: Universitas Terbuka. Tarigan, Djago. 1997. Pendidikan Bahasa dan Sastra Indonesia di Kelas Rendah. Jakarta: Universitas Terbuka.

Uno, Hamzah. 2008. Model Pembelajaran. Jakarta: Bumi Aksara.

Winataputra, Udin. 2007. Teori Belajar dan Pembelajaran. Jakarta: Universitas Terbuka.

Winataputra, Udin. 2004. Strategi Belajar Mengajar. Jakarta: Universitas Terbuka.

Wahyudin, Dinn. 2006. Pengantar Pendidikan. Jakarta: Universitas Terbuka. 